\title{
New indications for fully covered lumen-apposing metal stents: biliary stenting to treat post-sphincterotomy bleeding or ampullary stenosis
}

Stenting with standard biliary fully covered self-expandable metal stents (FCSEMSs) has been reported as successful treatment for complications after biliary sphincterotomy such as bleeding, perforation, or stenosis [1]. However, in some situations, such as a dilated common bile duct $(\mathrm{CBD})$ or large sphincterotomy, these stents are not watertight, which can lead to persistent bleeding and leakage, or a malfunction [1,2]. A new, shaped, large covered stent could be an interesting solution, with maximal radial and axial force achieving adequate local compression to allow calibration of a stenosis, hemostasis, or a watertight seal to be created $[3,4]$. Here, we report our early experience with the use of these new stents in the CBD in two patients ( $\triangleright$ Video 1 ).

The first patient was an 89-year-old woman who underwent a maximal recut after a previous sphincterotomy for residual stones in a dilated $C B D$. She represented 12 hours later with hypovolemic shock and melena. After resuscitation, she underwent an emergency endoscopic retrograde cholangiopancreatography (ERCP), which showed active arterial bleeding from the roof of the sphincterotomy. Injection of adrenaline, insertion of a standard 10-mm diameter FCSEMS, and forced coagulation of the visible vessel using a CoGasper did not achieve hemostasis. Because of the size of the sphincterotomy and the dilatation of the CBD, we decided to place a fully covered lumen-apposing metal stent (FCLAMS). A 4-cm × 14-mm FCLAMS was successfully delivered with complete hemostasis being achieved. Bleeding did not recur and the stent was removed 5 days later without complications.

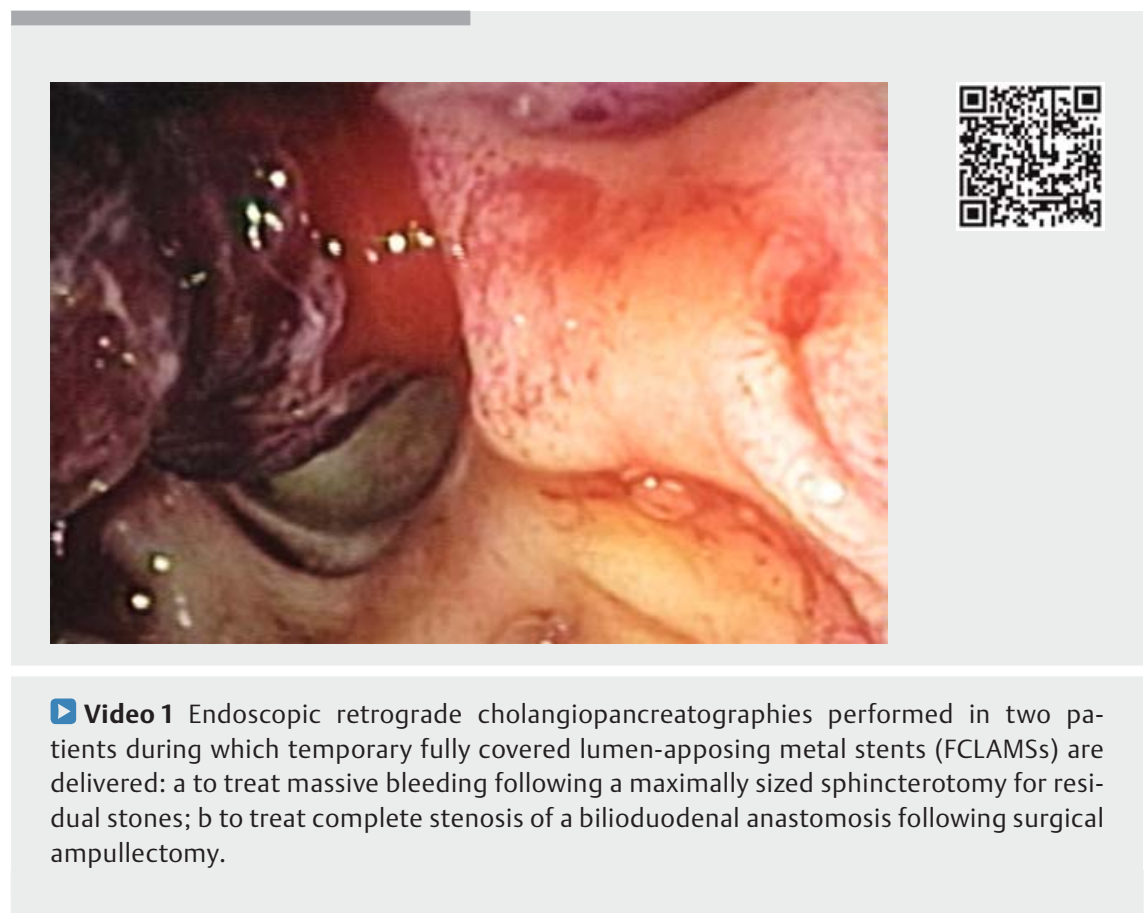

The second patient was a 67-year-old man who had undergone surgical resection of the pancreatic papilla for high grade dysplasia 3 months previously. He presented with acute cholangitis due to complete anastomotic stenosis of the CBD with marked dilatation. A $3-\mathrm{cm} \times$ 14-mm FCLAMS was successfully delivered. The patient was discharged on day 1 and has been scheduled for removal of the stent.

The present cases suggest that placement of a transpapillary FCLAMS could be an interesting alternative for treating post-sphincterotomy bleeding and to calibrate stenosis, in patients with a dilated CBD and/or a large sphincterotomy orifice.

Endoscopy_UCTN_Code_TTT_1AR_2AK
Competing interests

None

The authors

Gianfranco Donatelli ${ }^{1}$, Jean-Loup Dumont ${ }^{1}$, Serge Derhy' ${ }^{1}$, Bruno Meduri ${ }^{1}$, Stavros Dritsas $^{2}$, Brice Gayet ${ }^{3}$, David Fuks ${ }^{3}$

1 Department of Interventional Endoscopy, de Santé, Paris, France

2 Department of Gastroenterology, General Hospital, Fontainebleau, France

3 Department of Digestive Surgery, Institut Mutualiste Montsouris, Paris, France Peupliers Private Hospital, Ramsay Générale 
Corresponding author

\section{Gianfranco Donatelli, MD}

Department of Interventional Endoscopy, Ramsay Générale de Santé, Hôpital Privé des Peupliers, 8 Place de l'Abbé G. Hénocque, 75013, Paris, France

Fax: +33-01-44165615

donatelligianfranco@gmail.com

\section{References}

[1] Donatelli G, Dumont JL, Cereatti F et al. Revision of biliary sphincterotomy by re-cut, balloon dilation or temporary stenting: comparison of clinical outcome and complication rate (with video). Endosc Int Open 2017; 5: E395-E401

[2] Donatelli G, Cereatti F, Dumont JL et al. Postbiliary sphincterotomy bleeding despite covered metallic stent deployment. SAGE Open Med Case Rep 2016; 4: $2050313 \times 16645756$

[3] Khashab MA, Messallam AA, Penas I et al. International multicenter comparative trial of transluminal EUS-guided biliary drainage via hepatogastrostomy vs. Choledochoduodenostomy approaches. Endosc Int Open 2016; 4: E175-E181

[4] Yang D, Nieto JM, Siddiqui A et al. Lumenapposing covered self-expandable metal stents for short benign gastrointestinal strictures: a multicenter study. Endoscopy 2017; 49: 327-333

\section{Bibliography}

DOI https://doi.org/10.1055/s-0043-121563

Published online: 14.11.2017

Endoscopy 2018; 50: E36-E37

(c) Georg Thieme Verlag KG

Stuttgart · New York

ISSN 0013-726X

\section{ENDOSCOPY E-VIDEOS}

https:/|eref.thieme.de/e-videos

回直 Endoscopy E-Videos is a free Fection, reporting 回舴: on interesting cases and new techniques in gastroenterological endoscopy. All papers include a high quality video and all contributions are freely accessible online.

This section has its own submission website at https://mc.manuscriptcentral.com/e-videos 